\title{
Correction to: Upadacitinib improves patient-reported outcomes in patients with rheumatoid arthritis and inadequate response to conventional synthetic disease- modifying antirheumatic drugs: results from SELECT-NEXT
}

Vibeke Strand ${ }^{1}$, Janet Pope ${ }^{2}$, Namita Tundia ${ }^{3 *}$, Alan Friedman ${ }^{3}$, Heidi S. Camp ${ }^{3}$, Aileen Pangan ${ }^{3}$, Arijit Ganguli ${ }^{3}$, Mahesh Fuldeore ${ }^{3}$, Debbie Goldschmidt ${ }^{4}$ and Michael Schiff ${ }^{5}$

Correction to: Arthritis Res Ther (2019)21:272

https://doi.org/10.1186/s13075-019-2037-1

Following publication of the original article [1], the authors reported an error in some of the data values in Fig. 2a. The correct Fig. 2a can be seen below.

\section{Author details}

'Stanford University, Palo Alto, CA, USA. ${ }^{2}$ University of Western Ontario, London, ON, Canada. ${ }^{3}$ AbbVie Inc., North Chicago, IL, USA. ${ }^{4}$ Analysis Group, Inc., New York, NY, USA. ${ }^{5}$ University of Colorado, Denver, CO, USA.

Published online: 09 June 2020

\section{Reference}

1. Strand V, Pope J, Tundia N, et al. Upadacitinib improves patient-reported outcomes in patients with rheumatoid arthritis and inadequate response to conventional synthetic disease-modifying antirheumatic drugs: results from SELECT-NEXT. Arthritis Res Ther. 2019;21:272 https://doi.org/10.1186/s13075019-2037-1.

The original article can be found online at https://doi.org/10.1186/s13075019-2037-1.

* Correspondence: namita.tundia@abbvie.com

${ }^{3}$ AbbVie Inc., North Chicago, IL, USA

Full list of author information is available at the end of the article

(c) The Author(s). 2020 Open Access This article is licensed under a Creative Commons Attribution 4.0 International License, which permits use, sharing, adaptation, distribution and reproduction in any medium or format, as long as you give appropriate credit to the original author(s) and the source, provide a link to the Creative Commons licence, and indicate if changes were made. The images or other third party material in this article are included in the article's Creative Commons licence, unless indicated otherwise in a credit line to the material. If material is not included in the article's Creative Commons licence and your intended use is not permitted by statutory regulation or exceeds the permitted use, you will need to obtain permission directly from the copyright holder. To view a copy of this licence, visit http://creativecommons.org/licenses/by/4.0/ The Creative Commons Public Domain Dedication waiver (http://creativecommons.org/publicdomain/zero/1.0/) applies to the data made available in this article, unless otherwise stated in a credit line to the data. 


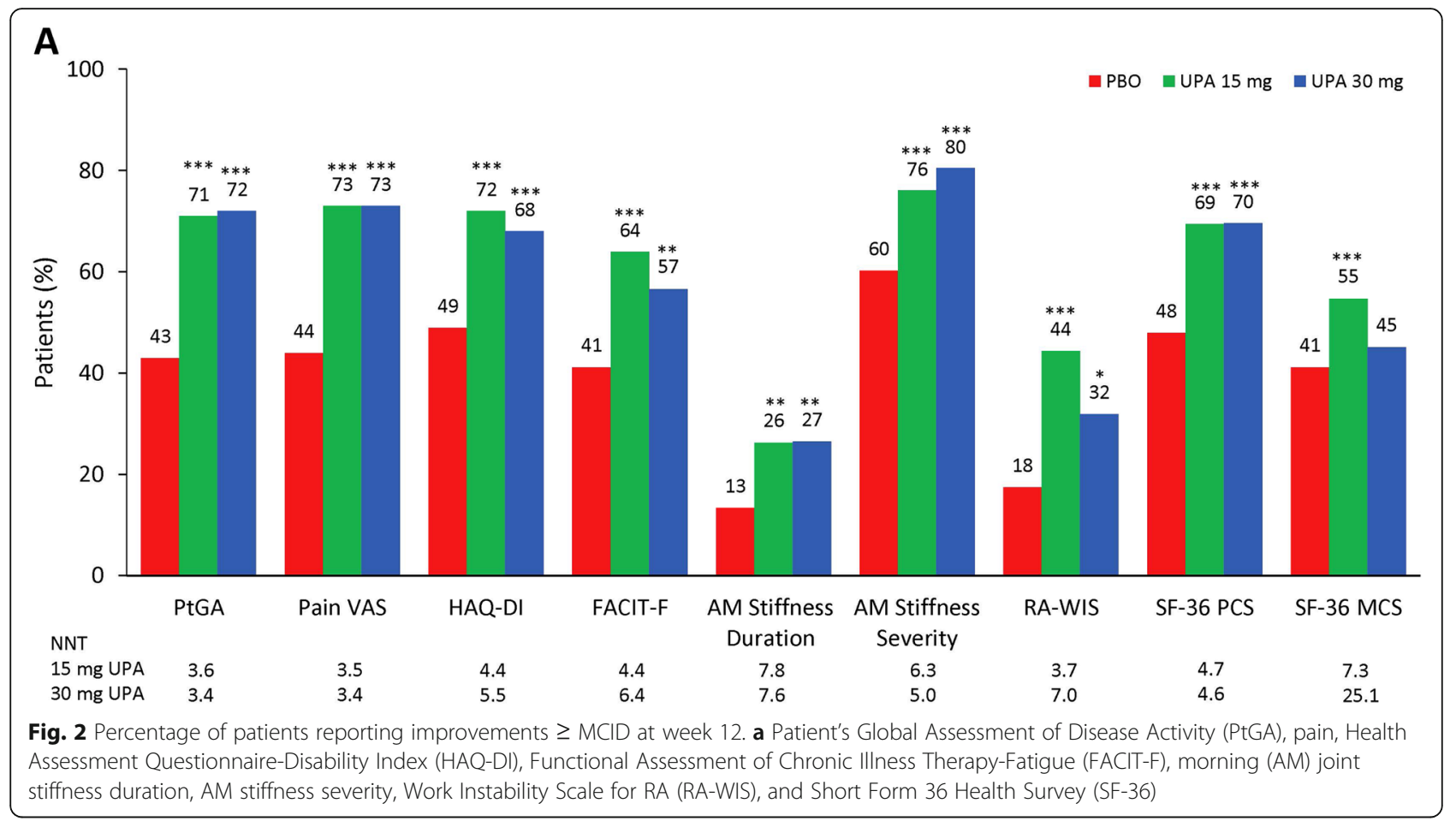

